Effects of conversion from a natural evergreen broadleaf forest

to a Moso bamboo plantation on the soil nutrient pools, microbial biomass and enzyme activities in a subtropical area

\title{
Cai, Xiaoqing
}

2018-08-15

Cai , X, Lin , Z , Penttinen , P , Li , Y , Li , Y , Luo , Y , Yue , T , Jiang , P \& Fu , W 2018 , ' Effects of conversion from a natural evergreen broadleaf forest to a Moso bamboo plantation on the soil nutrient pools, microbial biomass and enzyme activities in a subtropical area ' , Forest Ecology and Management, vol. 422 , pp. 161-171 . https://doi.org/10.1016/j.foreco.2018.04.022

http://hdl.handle.net/10138/326533

https://doi.org/10.1016/j.foreco.2018.04.022

cc_by_nc_nd

acceptedVersion

Downloaded from Helda, University of Helsinki institutional repository.

This is an electronic reprint of the original article.

This reprint may differ from the original in pagination and typographic detail.

Please cite the original version. 
plantation on the soil nutrient pools, microbial biomass and enzyme activities in a

4 Xiaoqing Cai ${ }^{\text {a, b }}$, Ziwen Lin ${ }^{\text {a, b }}$, Petri Penttinen ${ }^{\text {a, c }}$, Yongfu Li ${ }^{\text {a, b, * }}$, Yongchun Li ${ }^{\text {a, b }}, \mathrm{Yu}$

$5 \quad$ Luo $^{d}$, Tian Yue ${ }^{\text {a, b }}$, Peikun Jiang ${ }^{\text {a, b }}$, Weijun Fu ${ }^{\text {a, b }}$

6

$7 \quad$ a State Key Laboratory of Subtropical Silviculture, Zhejiang Provincial Key Laboratory of

8 Carbon Cycling in Forest Ecosystems and Carbon Sequestration, Zhejiang A \& F

9 University, Lin'an 311300, China

$10 \mathrm{~b}^{\mathrm{b}}$ Zhejiang Provincial Collaborative Innovation Center for Bamboo Resources and High-

11 efficiency Utilization, Zhejiang A \& F University, Lin'an 311300, China

$12{ }^{\mathrm{c}}$ Department of Environmental Sciences, PO Box 65 (Viikinkaari 2a), 00014, University

13 of Helsinki, Finland

14 d Zhejiang Provincial Key Laboratory of Agricultural Resources and Environment,

15 Zhejiang University, Hangzhou 310058, China

$16 *$ Corresponding author:

17 E-mail: yongfuli@zafu.edu.cn (Y. Li)

$18 \quad$ Tel.: +86-571-611-02592; Fax.: +86-571-637-40889

19 Number of text pages: $35 ; \quad$ Number of figures: $7 ; \quad$ Number of tables: 1

20 Submitted to: Forest Ecology and Management

21 Type of papers: Original Research Paper (Full Length Article)

22 Date of preparation: February 23, 2018

23 Revised: April 8, 2018 


\section{Abstract}

Converting natural forests to plantations would markedly change soil physiochemical and biological properties, as a consequence of changing plant vegetative coverage and management practices. However, the effects of such land-use change on the soil nutrient pools and related enzymes activities still remain unclear. The aim of this study was to explore the effects of conversion from natural evergreen broadleaf forests to Moso bamboo plantations on the pool sizes and forms of soil N, P and K, microbial biomass, and nutrient cycling related enzyme activities. Soil samples from four adjacent evergreen broadleaf forest-Moso bamboo plantation pairs were collected from a subtropical region in Zhejiang Province, China. The soil organic C (SOC), total N (TN), total P (TP) and total K (TK) concentrations and stocks and different N, P and $\mathrm{K}$ forms were measured, and the microbial biomass $\mathrm{C}(\mathrm{MBC})$, microbial biomass $\mathrm{N}(\mathrm{MBN})$, microbial biomass $\mathrm{P}(\mathrm{MBP})$ and four soil enzymes (protease, urease, acid phosphatase and catalase) were determined. The results showed that converting broadleaf forests to Moso bamboo plantations decreased the concentration and stock of SOC but increased those of TK in both soil layers (0-20 and 20-40 cm), and such land-use change increased the concentration and stock of TN and TP only in the $0-20 \mathrm{~cm}$ soil layer $(P<0.05)$. This land-use conversion increased the concentrations of $\mathrm{NH}_{4}{ }^{+}-\mathrm{N}, \mathrm{NO}_{3}{ }^{-}-\mathrm{N}$, resin- $\mathrm{P}_{\mathrm{i}}, \mathrm{NaHCO}_{3}-\mathrm{P}_{\mathrm{i}}, \mathrm{NaOH}-\mathrm{P}_{\mathrm{i}}, \mathrm{HCl}-\mathrm{P}_{\mathrm{i}}$, available $\mathrm{K}$ and slowly available $\mathrm{K}$, but decreased the concentrations of water-soluble organic nitrogen (WSON), $\mathrm{NaHCO}_{3}-\mathrm{P}_{\mathrm{o}}$ and NaOH- $\mathrm{P}_{\mathrm{o}}(P<0.05)$. Further, this land-use change decreased the microbial biomass and activities of protease, urease, acid phosphatase and catalase $(P<0.05)$. In addition, the acid phosphatase activity correlated 
positively with the concentrations of $\mathrm{MBP}$ and $\mathrm{NaHCO}_{3}-\mathrm{P}_{\mathrm{o}}$, and the activities of urease and protease correlated positively with the concentrations of MBN and WSON $(P<0.01)$.

49 To conclude, converting natural broadleaf forests to Moso bamboo plantations had

50 positive effects on soil inorganic $\mathrm{N}, \mathrm{P}$ and $\mathrm{K}$ pools, and negative effects on soil organic $\mathrm{N}$

51 and P pools, and on N- and P-cycling related enzyme activities. Therefore, management

52 practices that increase organic nutrient pools and microbial activity are needed to be

53 developed to mitigate the depletion of organic nutrient pools after the land-use conversion.

54

55 Keywords: Evergreen broadleaf forest; Land-use conversion; Microbial biomass; Moso bamboo plantation; Soil nutrient form; Soil enzyme. 


\section{Introduction}

Land-use conversion can significantly affect the soil physicochemical and biological properties (Yang et al., 2004; Don et al., 2011; Moghimian et al., 2017). Over the past few decades, in order to gain higher economic benefits and to supply the growing demands of timber, paper and fuel, among other commodities, the conversion from natural forests to plantations is becoming more frequent (Burton et al., 2007; Li et al., 2014; Hu et al., 2018).

To increase the growth of plantations after land-use change, intensive management practices, mainly including fertilization, understory vegetation control, and deep ploughing, have been commonly adopted (Li et al., 2013; Zhang et al., 2015a; Dangal et al., 2017; Zhang et al., 2017a). Various studies have revealed that the intensive management practices applied can significantly change the soil $\mathrm{pH}$, nutrient status, and microbial biomass and community composition (Li et al., 2013; Yuan et al., 2015; Xie et al., 2017), and consequently influence soil fertility and plant growth (Pransiska et al., 2016; Tiecher et al., 2017). Therefore, it is great of significance to investigate the effects of landuse change and subsequent management practices on the pool sizes and forms of soil nutrients and associated enzyme activities.

The effects of land-use change from natural forest to plantation on soil nutrient status and associated enzyme activities may include the following: (1) the input of exogenous fertilizer can have a direct effect on the pool sizes and forms of soil nutrients (Chang et al., 2007; Sainju et al., 2012; Yang et al. 2017; Li et al. 2018), and (2) the differences in chemical composition and root exudates of different vegetation types may change the 
microbial growth environment, which affects microbial biomass and soil enzyme activity (Yang et al., 2010; Li et al., 2011; Wang et al., 2013; Yuan et al., 2015). For example, the input of exogenous organic fertilizer and root exudates can increase the availability of water-soluble nitrogen (N) (Scott and Rothstein, 2011; Sainju et al., 2012; Li et al., 2017a). In addition, an increase in $\mathrm{N}$ fertilizer application can reduce soil enzyme activity and microbial biomass (Shen et al., 2010; Zhang et al., 2015b). Previous studies showed that understory vegetation plays important roles in cycling nutrients and decreasing soil erosion (Fukuzawa et al., 2006; Zhang et al., 2010).

The classification of soil nutrients can help to determine soil nutrient status (Ross et al., 1999; Yang et al., 2010). Different forms of $\mathrm{N}$, such as $\mathrm{NH}_{4}{ }^{+}-\mathrm{N}, \mathrm{NO}_{3}{ }^{-}-\mathrm{N}$ and watersoluble organic $\mathrm{N}$ (WSON), can jointly indicate the $\mathrm{N}$ supply capacity of soils (Schimel and Bennett, 2004; Chen and Xu, 2008; Yan et al., 2008; Wu et al., 2010). The different forms of phosphorus $(\mathrm{P})$ in soils are formed through the combination of $\mathrm{P}$ with different mineral components and can significantly affect N- and P-cycling (Yang et al., 2010; Wei et al., 2017). In addition, the soil potassium (K) supply is closely associated with the transformation rate of different forms of $\mathrm{K}$ in soils (Darunsontaya et al., 2012). The different forms of nutrients respond differently to land-use change. For example, Ouyang et al. (2013) reported that after conversion from wetland to paddy field, the total $\mathrm{K}$ concentration increased but the available $\mathrm{K}$ concentration decreased in soils. Yang et al. (2004) reported that converting secondary forests to rubber plantations increased the concentration of inorganic $\mathrm{N}$ but decreased the concentration of total N. In addition, Yang et al. (2010) found that converting natural forests to larch plantations increased the 
concentrations of total P (TP) and inorganic P (IP) but decreased the concentrations of microbial biomass $\mathrm{P}(\mathrm{MBP})$ and organic $\mathrm{P}(\mathrm{OP})$. Therefore, exploring the responses of different forms of soil nutrients to land-use change will enable us to elucidate the mechanisms associated with the land-use conversion effects on the soil nutrient status.

Soil microbes play an important role in the decomposition and mineralization of soil organic matter (Malchair and Carnol, 2009; Guo et al., 2016; Ge et al., 2017; Li et al., 2017b; Luo et al., 2017). Soil enzymes are closely related to the transformation of soil nutrients, and their activities are closely associated with the level of soil organic matter, soil physicochemical properties and soil microbial biomass (Xu et al., 2010; Liu et al., 2015; Chavarría et al., 2016; Ma et al., 2016). For example, Bhattacharyya et al. (2005) found that there was a pronounced linear correlation between soil urease and microbial biomass. Additionally, Yang et al. (2010) found that acid phosphatase activity was positively correlated with the concentrations of $\mathrm{NaHCO}_{3}-\mathrm{P}_{\mathrm{i}}, \mathrm{NaHCO}_{3}-\mathrm{P}_{\mathrm{o}}$, and MBP in a subtropical forest soil. Land-use change can markedly affect the soil enzyme activity as well as the soil microbial biomass and nutrient forms (Dawoe et al., 2014; Guo et al., 2016). However, it remains unclear whether the changes in soil enzyme activity caused by land-use change are closely linked with the changes in soil microbial biomass or nutrient forms.

Natural evergreen broadleaf forests contribute to maintain biodiversity; these forests are considered to be an important vegetation type in the subtropical regions of China (Wang et al., 2007). However, large areas of natural forests have been transformed into plantations over the past two decades (Yan et al., 2015; Chen et al., 2017), most 
commonly into bamboo plantations (Guan et al., 2015). The area of Moso bamboo (Phyllostachys edulis) plantations has increased to 4.2 million ha due to their substantial economic benefit (Yuen et al., 2017). At present, most of the Moso bamboo plantations are intensively managed, with the application of fertilizers, the removal of understory vegetation, and tillage (Li et al., 2013; Yang et al., 2017). It is expected that conversion from natural evergreen broadleaf forests to Moso bamboo plantations, in combination with subsequent management practices, will markedly change the soil physical, chemical and biological characteristics. However, the effects of the aforementioned land-use change on soil nutrient pools and enzyme activities remain unclear. Therefore, the purposes of the present study were (1) to analyze the effects of conversion from evergreen broadleaf forests to Moso bamboo plantations on the pool sizes and different forms of soil nutrients, (2) to investigate the aforementioned land-use conversion effects on the soil microbial biomass and activity of soil enzymes regarding nutrient cycling, and (3) to reveal the relationship between soil enzyme activity and the different forms of soil nutrients or soil microbial biomass.

\section{Materials and methods}

\subsection{Experimental site}

The study was carried out in Congkeng $\left(30^{\circ} 14^{\prime} \mathrm{N}, 119^{\circ} 42^{\prime} \mathrm{E}\right)$, Hangzhou, Zhejiang, China. The study area belongs to a subtropical monsoon climate zone with four distinct seasons, with an average annual temperature of $15.8^{\circ} \mathrm{C}$ and average annual precipitation 
of $1420 \mathrm{~mm}$. The annual sunshine duration and frost-free period of this site are 1946 hours and 239 days, respectively. The elevation of the study area is approximately $150 \mathrm{~m}$. The soils at this experimental site are classified as Ferralsols (World Reference Base for Soil Resources (WRB) 2006).

We chose two different land-use types, i.e., natural evergreen broadleaf forests and Moso bamboo plantations, to investigate the differences in soil properties. The main tree species in the natural evergreen broadleaf forests were Cyclobalanopsis glauca, Castanopsis eyrie, and Castanopsis sclerophylla, which accounted for approximately $70 \%$ of the canopy cover. The understory vegetation in this natural forest was mainly Litsea cubeba, Lindera glauca, and Camellia cuspidata, of which the surface cover was approximately $85 \%$. Part of the natural evergreen broadleaf forests had been transformed into Moso bamboo plantations. The Moso bamboo plantation in the present study was established in 2004. The bamboo plantation had been managed intensively for 11 years after the land-use conversion. The stocking density in the bamboo plantation was 3,000 stems $\mathrm{ha}^{-1}$, with $10.1 \mathrm{~cm}$ mean diameter at breast height. Every year from late June to early July the bamboo plantation was fertilized with urea (200 $\left.\mathrm{kg} \mathrm{N} \mathrm{ha}^{-1}\right)$, superphosphate (60 $\left.\mathrm{kg} \mathrm{P} \mathrm{ha}^{-1}\right)$, and potassium chloride $\left(70 \mathrm{~kg} \mathrm{~K} \mathrm{ha}^{-1}\right)$. The fertilizer was usually applied on the soil surface, followed by plowing to a depth of $30-35 \mathrm{~cm}$. The understory vegetation in the bamboo plantation was manually removed each year.

\subsection{Experimental design and soil sampling}



on soil properties. One paired-plot included two adjacent plots, i.e., one in the natural evergreen broadleaf forest and the other in the Moso bamboo plantation. Each paired plot had the same geographic and environmental factors, including soil type, slope (15-20 $)$ and aspect (south). We selected four different locations within $\sim 3 \mathrm{~km}^{2}$ in the area described above to establish four different paired plots in April 2015; the plot size was 20 bulk density of $1.06 \mathrm{~g} \mathrm{~cm}^{-3}$, sand of $324 \mathrm{~g} \mathrm{~kg}^{-1}$, silt of $401 \mathrm{~g} \mathrm{~kg}^{-1}$, and clay of $275 \mathrm{~g} \mathrm{~kg}^{-1}$. $\mathrm{m} \times 20 \mathrm{~m}\left(400 \mathrm{~m}^{2}\right)$. Within one paired-plot, the distance between the two plots (one in the natural evergreen broadleaf forest and the other in the Moso bamboo plantation) was less than $100 \mathrm{~m}$, and there were 4 replications for each land-use type.

In each plot, we collected soil samples from five randomly selected points at the $0-20$ and $20-40 \mathrm{~cm}$ soil layers. For each soil layer, the five samples were thoroughly mixed to form a composite sample. The soil samples were kept on ice before further processing. A 2-mm sieve was used to homogenize the samples, and visible roots were removed. Samples were divided into two portions: one portion was stored at $4{ }^{\circ} \mathrm{C}$ for further analyses, and the other portion was air-dried. We used a bulk density corer with a $200-\mathrm{cm}^{3}$ volume to collect samples from the two soil layers to determine the bulk density. The average values for the selective physicochemical properties (see methods described below) in the $0-20 \mathrm{~cm}$ soil layer for the aforementioned two forest types were listed below: (1) natural evergreen broadleaf forest: $\mathrm{pH}$ of 5.67, bulk density of $0.96 \mathrm{~g} \mathrm{~cm}^{-3}$, sand of $301 \mathrm{~g}$ $\mathrm{kg}^{-1}$, silt of $413 \mathrm{~g} \mathrm{~kg}^{-1}$, and clay of $286 \mathrm{~g} \mathrm{~kg}^{-1}$; (2) Moso bamboo plantation: $\mathrm{pH}$ of 5.16 , 


\subsection{Determination of soil physicochemical properties}

The soil $\mathrm{pH}$ was measured at a soil-to-water ratio of 1:2.5 (w:v) using a $\mathrm{pH}$ meter.

The soil moisture content was measured by calculating the mass loss after oven drying at $105{ }^{\circ} \mathrm{C}$ for more than 12 hours. The soil bulk density was determined by collecting a fresh 20-g soil subsample from a metal density corer with known volume and oven drying the sample for more than 24 hours at a temperature of $105^{\circ} \mathrm{C}$. The concentrations of soil organic carbon (SOC) and total $\mathrm{N}(\mathrm{TN})$ were determined using an elemental analyzer (model CHN-O-RAPID, Heraeus, Germany). The total P (TP) concentration was determined by digesting soil samples with a mixture of concentrated $\mathrm{H}_{2} \mathrm{SO}_{4}$ and $\mathrm{HClO}_{4}$, and the molybdate-blue colorimetry method (Murphy and Riley 1962) was used to measure the $\mathrm{P}$ concentration in the digest. The soil total $\mathrm{K}(\mathrm{TK})$ concentration was determined using the $\mathrm{NaOH}$ melting method according to Hanway and Heidel (1952). Soil texture was determined using the pipette method after pre-treating the soil samples with solutions of $\mathrm{H}_{2} \mathrm{O}_{2}$ and $\mathrm{Na}_{4} \mathrm{P}_{2} \mathrm{O}_{7}$ (Gee and Bauder 1986). The stocks of SOC, TN, TP and

TK were calculated using the following formula:

$$
Y_{\text {stock }}\left(\mathrm{Mg} \mathrm{ha}^{-1}\right)=X \times B D \times \text { th } \times 0.1
$$


The concentrations of $\mathrm{NO}_{3}{ }^{-}-\mathrm{N}$ and $\mathrm{NH}_{4}{ }^{+}-\mathrm{N}$ in each soil sample were determined according to the method of Li et al. (2014). Briefly, a soil sample was extracted with $\mathrm{KCl}$ solution $\left(2 \mathrm{~mol} \mathrm{~L}{ }^{-1}\right)$, and the concentrations of $\mathrm{NO}_{3}{ }^{-}-\mathrm{N}$ and $\mathrm{NH}_{4}{ }^{+}-\mathrm{N}$ in the extract were determined using a Dionex ICS 1500 ion chromatograph (Dionex Corp., Atlanta, USA).

The WSON concentration was determined according to Jones and Willett et al. (2006). In short, a fresh subsample equivalent to $20 \mathrm{~g}$ of oven-dried soil was suspended in $40 \mathrm{~mL}$ of distilled water, shaken for 0.5 hours at $150 \mathrm{rpm}$ at $25^{\circ} \mathrm{C}$ and then centrifuged for 20 minutes at $8,000 \times \mathrm{g}$. The supernatant was passed through a $0.45-\mu \mathrm{m}$ membrane filter (Millipore Corp, USA). The concentration of water-soluble N (WSN) in the filtrate was measured using an automated TOC-TN analyzer (TOC-Vcph, Shimadzu, Kyoto, Japan). The concentrations of $\mathrm{NH}_{3}{ }^{-}-\mathrm{N}$ and $\mathrm{NH}_{4}{ }^{+}-\mathrm{N}$ in the filtrate were determined using an ion chromatograph, and the WSON concentration was calculated using the following formula:

\subsection{Determination of $P$ forms}

$$
\mathrm{WSON}=\mathrm{WSN}-\left(\mathrm{NO}_{3}{ }^{-}-\mathrm{N}\right)-\left(\mathrm{NH}_{4}{ }^{+}-\mathrm{N}\right)
$$


with a strip of $\mathrm{NaHCO}_{3}$-form anion exchange resin membrane (BDH No. 55164) pretreated by the method of Schoenau and Huang (1991), the suspension was shaken for 16 hours at $150 \mathrm{rpm}$ at $25^{\circ} \mathrm{C}$, and the $\mathrm{P}$ absorbed into the resin membrane (resin- $\mathrm{P}_{\mathrm{i}}$ ) was recovered by shaking the resin membrane in $50 \mathrm{~mL}$ of $0.5 \mathrm{~mol} \mathrm{~L}-1 \mathrm{HCl}$ for $1 \mathrm{~h}$. (2) $\mathrm{NaHCO}_{3}-\mathrm{P}_{\mathrm{i}}$ and $\mathrm{NaHCO}_{3}-\mathrm{P}_{\mathrm{o}}$ : two drops of toluene were added to minimize organic $\mathrm{P}$ decomposition to the residue from (1) before shaking in $30 \mathrm{~mL}$ of $0.5 \mathrm{~mol} \mathrm{~L}^{-1} \mathrm{NaHCO}_{3}$ $\left(\mathrm{pH}=8.5\right.$ ) for 16 hours. (3) NaOH- $\mathrm{P}_{\mathrm{i}}$ and $\mathrm{NaOH}-\mathrm{P}_{\mathrm{o}}: 30 \mathrm{~mL}$ of $0.1 \mathrm{~mol} \mathrm{~L}-1 \mathrm{NaOH}$ was added to the residue from (2) and then shaken for 16 hours. (4) HCl- $\mathrm{P}_{\mathrm{i}}$ : the residue from (3) was shaken in $30 \mathrm{~mL}$ of $1.0 \mathrm{~mol} \mathrm{~L}-1 \mathrm{HCl}$ for 16 hours. (5) Residual-P: the residue from (4) was digested in concentrated $\mathrm{H}_{2} \mathrm{SO}_{4}$ and $\mathrm{H}_{2} \mathrm{O}_{2}$, followed by shaking for 16 hours. After steps (1) to (5), the suspension was centrifuged at $12,000 \times g$ for 10 minutes. The supernatants were passed through a $0.45-\mu \mathrm{m}$ membrane filter (Millipore Corp., USA), and the inorganic $\mathrm{P}$ concentration in the filtrates were measured using the molybdate-blue method (Murphy and Riley, 1962). In (2) and (3), the TP concentration in the extracts was measured by digesting the extracts in concentrated $\mathrm{H}_{2} \mathrm{SO}_{4}$ and $\mathrm{H}_{2} \mathrm{O}_{2}$, and the organic $\mathrm{P}$ concentration in the extracts was calculated as the difference between the TP concentration and the inorganic $\mathrm{P}$ concentration.

\subsection{Analysis of K forms}

The different forms of soil $\mathrm{K}$ determined included available $\mathrm{K}$, slowly available $\mathrm{K}$ and mineral $\mathrm{K}$. The available $\mathrm{K}$ concentration was determined by the method of Zhang et 
257

al. (2013). Briefly, $10 \mathrm{~g}$ of oven-dried soil sample was suspended in $50 \mathrm{~mL}$ of $1.0 \mathrm{~mol} \mathrm{~L}^{-1}$ $\mathrm{NH}_{4} \mathrm{OAc}$, shaken for 0.5 hours at $150 \mathrm{rpm}$ at $25^{\circ} \mathrm{C}$, and the suspension was centrifuged at $5,000 \times \mathrm{g}$ for 10 minutes and then passed through a $0.45-\mu \mathrm{m}$ membrane filter (Millipore Corp, USA). The concentration of $\mathrm{K}$ in the filtrate was measured using a flame photometer (Tiecher et al. 2017). The slowly available K concentration was determined by suspending $10 \mathrm{~g}$ of oven-dried soil in $50 \mathrm{~mL}$ of $1.0 \mathrm{~mol} \mathrm{~L}^{-1} \mathrm{HNO}_{3}$, heated to boiling in an oil bath for 10 minutes, transferred to a $100-\mathrm{mL}$ volumetric flask, and the $\mathrm{K}$ concentration was measured using a flame photometer. The soil total K (TK) concentration for each soil sample was determined using the $\mathrm{NaOH}$ melting method (Hanway and Heidel, 1952).

Slowly available $\mathrm{K}$ was calculated as the difference between the concentration of $\mathrm{K}$ extracted by the hot $\mathrm{HNO}_{3}$ solution and the concentration of the $\mathrm{K}$ extracted by the $\mathrm{NH}_{4} \mathrm{OAc}$ solution. Mineral $\mathrm{K}$ was calculated as the difference between the concentration of total $\mathrm{K}$ and the concentration of the $\mathrm{K}$ extracted by the hot $\mathrm{HNO}_{3}$ solution.

\subsection{Analysis of soil microbial biomass and soil enzymes} were determined using the chloroform fumigation- $\mathrm{K}_{2} \mathrm{SO}_{4}$ extraction method as described in Vance et al. (1987). In brief, fumigated and non-fumigated soil samples were suspended in $40 \mathrm{~mL}$ of $0.5 \mathrm{~mol} \mathrm{~L}^{-1} \mathrm{~K}_{2} \mathrm{SO}_{4}$, shaken at $150 \mathrm{rpm}$ for 30 minutes at $25^{\circ} \mathrm{C}$, centrifuged for 5 minutes at $3500 \times \mathrm{g}$, and the supernatants were passed through a $0.45-\mu \mathrm{m}$ membrane filter (Millipore Corp, USA). The concentrations of $\mathrm{C}$ and $\mathrm{N}$ in the extracts were measured 
in an automated TOC-TN analyzer (TOC-Vcph, Shimadzu, Kyoto, Japan). The soil MBC concentration was calculated as the difference in the concentration of $\mathrm{C}$ between the fumigated and non-fumigated samples (Wu et al., 1990; Burton et al., 2010). Similarly, the soil MBN concentration was calculated as the difference in the concentration of $\mathrm{N}$ between the fumigated and non-fumigated samples (Li et al., 2014). The concentration of MBP was determined following the method of Brookes et al. (1982). Briefly, the MBP was calculated as the difference between the concentrations of inorganic $\mathrm{P}$ extracted with $0.5 \mathrm{~mol} \mathrm{~L}^{-1} \mathrm{NaHCO}_{3}(\mathrm{pH}=8.5)$ from fumigated and non-fumigated soil.

The soil protease (EC 3.4.2.21-24) activity was measured following the method of Ladd and Butler (1972). $1 \mathrm{~g}$ of fresh sample was mixed with $2.5 \mathrm{~mL}$ of Tris buffer (0.1 mol $\mathrm{L}^{-1}, \mathrm{pH}=8.1$ ) and $2.5 \mathrm{~mL}$ of $2 \%$ sodium caseinate, and incubated at $50^{\circ} \mathrm{C}$ for 2 hours. At the end of the incubation, $1 \mathrm{~mL}$ of $17.5 \%$ trichloroacetic acid (TCA) was added, then centrifuged for 10 minutes at $5,000 \times g .2 \mathrm{~mL}$ of the supernatant was mixed with $3.0 \mathrm{~mL}$ $\mathrm{Na}_{2} \mathrm{CO}_{3}\left(1.4 \mathrm{~mol} \mathrm{~L}^{-1}\right)$ and $1 \mathrm{~mL}$ threefold diluted Folin-Ciocalteu reagent. After 10 minutes, the absorbance was determined at $700 \mathrm{~nm}$. The protease activity is expressed as the amount of tyrosine released per hour per gram of soil $\left(\mu \mathrm{mol} \mathrm{g} \mathrm{g}^{-1} \mathrm{~h}^{-1}\right)$.

The soil urease (EC 3.5.1.5) activity was determined following the method described in Kandeler and Gerber (1988). Briefly, a fresh soil sample equivalent to $5 \mathrm{~g}$ of oven-dried soil was suspended in $2.5 \mathrm{~mL}$ of $80 \mathrm{mmol} \mathrm{L}^{-1}$ urea and $20 \mathrm{~mL}$ of Tris buffer $(0.075 \mathrm{~mol}$ $\mathrm{L}^{-1}, \mathrm{pH}=10$ ), and incubated at $37^{\circ} \mathrm{C}$ for 2 hours. After incubation, $50 \mathrm{~mL}$ of a mixture of $1 \mathrm{~mol} \mathrm{~L}^{-1} \mathrm{KCl}$ and $10 \mathrm{mmol} \mathrm{L}^{-1} \mathrm{HCl}$ was added, and the suspension was shaken at 125 rpm for 30 minutes. The suspension passed through a filter, and the concentration of 
ammonia in the filtrate was determined using the colorimetric method described in Marschner et al. (2003). The urease activity is expressed as the amount of $\mathrm{NH}_{3}-\mathrm{N}$ produced per unit mass of soil per hour $\left(\mu \mathrm{mol} \mathrm{g} \mathrm{g}^{-1} \mathrm{~h}^{-1}\right)$.

The soil acid phosphatase (EC 3.1.3.2) activity was determined following the method of Tabatabai and Bremner (1969). A fresh soil sample equivalent to $1 \mathrm{~g}$ of oven-dried soil was suspended in $0.2 \mathrm{~mL}$ of toluene, $4 \mathrm{~mL}$ of acetate buffer solution $(\mathrm{pH}=6.5)$ and $1 \mathrm{~mL}$ of $50 \mathrm{mmol} \mathrm{L}-1 p$-nitrophenol phosphate solution. The suspension was shaken at $150 \mathrm{rpm}$ at $37^{\circ} \mathrm{C}$ for 1 hour, and then $1 \mathrm{~mL}$ of $\mathrm{CaCl}_{2}$ solution $\left(0.5 \mathrm{~mol} \mathrm{~L}^{-1}\right)$ and $4 \mathrm{~mL}$ of $\mathrm{NaOH}$ solution $\left(0.5 \mathrm{~mol} \mathrm{~L}^{-1}\right)$ were added. After shaking for several seconds, the suspension was passed through filter paper, and the absorbance of the filtrate was determined at $400 \mathrm{~nm}$. The acid phosphatase activity is expressed as the amount of $p$-nitrophenyl produced per unit mass of soil per hour $\left(\mu \mathrm{mol} \mathrm{g} \mathrm{g}^{-1} \mathrm{~h}^{-1}\right)$.

The soil catalase (EC 1.11.1.6) activity was measured following the method of Johnson and Temple (1964). A fresh soil sample equivalent to $2 \mathrm{~g}$ of oven-dried soil was suspended in $40 \mathrm{~mL}$ of distilled water and $5 \mathrm{~mL}$ of $0.3 \% \mathrm{H}_{2} \mathrm{O}_{2}$, and shaken at $150 \mathrm{rpm}$ for 20 minutes at $25^{\circ} \mathrm{C}$. Then, $5 \mathrm{~mL}$ of $3 \mathrm{~mol} \mathrm{~L}^{-1}$ sulfuric acid was added, and the mixture was titrated using $0.1 \mathrm{~mol} \mathrm{~L}^{-1} \mathrm{KMnO}_{4}$ solution. The baseline was determined by titrating a mixture of $5 \mathrm{~mL}$ of $0.3 \% \mathrm{H}_{2} \mathrm{O}_{2}$ and $5 \mathrm{~mL}$ of $3 \mathrm{~mol} \mathrm{~L}^{-1}$ sulfuric acid with $0.1 \mathrm{~mol} \mathrm{~L}^{-1}$ $\mathrm{KMnO}_{4}$. The catalase activity is expressed as the amount of consumption of $\mathrm{KMnO}_{4}$ per hour per gram of soil $\left(\mu \mathrm{mol} \mathrm{g} \mathrm{g}^{-1} \mathrm{~h}^{-1}\right)$. 
The data presented in this paper are the mean values of four replicates. One-way analysis of variance (ANOVA) and the least significant difference (LSD) test was adopted to determine the land-use conversion effects on the soil physiochemical properties, microbial biomass and enzyme activities. Prior to performing the ANOVA, the normality and homogeneity of variance were evaluated, and data were log-transformed when needed. in the bamboo plantation was higher than that in the broadleaf forest (Fig. 1g). The total $\mathrm{N}$ and $\mathrm{P}$ concentrations in the bamboo plantation were higher than those in the broadleaf forest in the $0-20 \mathrm{~cm}$ soil layer, while no differences were observed in the $20-40 \mathrm{~cm}$ layer (Fig. 1c, e). The effects of land-use conversion on the total C, N, P and K stocks were 

plantation were higher than those in the broadleaf forest in the $0-20 \mathrm{~cm}$ soil layer, while no differences were detected in the 20-40 cm layer (Table 1). The $\mathrm{NaOH}-\mathrm{P}_{\mathrm{o}}$ concentration in the bamboo plantation was lower than that in the broadleaf forest in the $0-20 \mathrm{~cm}$ soil layer, while no significant difference was found in the 20-40 cm layer (Table 1). 


74

concentrations in the Moso bamboo plantation were higher than those in the evergreen broadleaf forest (Fig. 3a-c). The mineral K concentration in the bamboo plantation was higher than that in the broadleaf forest in the $0-20 \mathrm{~cm}$ soil layer, while no difference was found in the 20-40 cm layer (Fig. 3d).

\subsection{Soil microbial biomass and enzyme activities}

$$
\text { Regardless of soil layer, the MBC, MBN and MBP concentrations in the Moso }
$$

bamboo plantation were higher than those in the evergreen broadleaf forest (Fig. 4).

Regardless of soil layer, the activities of protease, urease, and acid phosphatase in the bamboo plantation were lower than those in the broadleaf forest (Fig. $5 \mathrm{a}-\mathrm{c})$. The catalase activity in the bamboo plantation was lower than that in the broadleaf forest in the $0-20$ $\mathrm{cm}$ soil layer, while no difference was found in the $20-40 \mathrm{~cm}$ layer (Fig. 5d). Acid phosphatase activity correlated positively with $\mathrm{MBP}$ and $\mathrm{NaHCO}_{3}-\mathrm{P}_{\mathrm{o}}$ (Fig. 6), and urease and protease activities correlated positively with the concentrations of MBN and WSON (Fig. 7) $(P<0.01)$.

\section{Discussion}

\subsection{Land-use conversion effects on soil nutrient pools}


1). This result coincides with that of Guillaume et al. (2015), who reported that conversion from lowland rainforests to intensively managed rubber plantations significantly decreased the SOC stock. The decrease in concentration and stock of SOC due to the land-use change in our study has two possible explanations. Practices of fertilization and tillage may accelerate the mineralization of SOC and the leaching of soluble soil organic matter

plantation increased the concentrations of $\mathrm{NO}_{3}{ }^{-}-\mathrm{N}$ and $\mathrm{NH}_{4}{ }^{+}-\mathrm{N}$ (Fig. 2), in agreement with conversion from secondary forest to a larch plantation. In addition, we also found that the aforementioned land-use change significantly decreased the WSON concentration (Fig. 2),

\subsection{Land-use conversion effects on different soil $N$ forms}

Yang et al. (2004) who reported that the concentration of $\mathrm{NO}_{3}{ }^{-}-\mathrm{N}$ increased after the 
414 which accords with the result of Li et al. (2014), who reported that the conversion of

415 natural shrub forests to intensively managed Chinese chestnut plantations significantly

416 reduced the WSON concentration in the soil.

The changes in soil $\mathrm{N}$ forms caused by land-use change can be attributed to a number

of possible mechanisms. Intensive managements that include fertilization, tillage and

understory vegetation removal, could lead to a decrease in water and soil conservation

ability, and consequently cause the loss of WSON (Yüksek et al., 2009; Sheng et al.,

2015). Fertilization can accelerate the mineralization of organic $\mathrm{N}$ and enhance the uptake

of soluble organic $\mathrm{N}$ by plants, consequently reducing the WSON concentration in soils

(Schimel and Bennett, 2004; Tao et al., 2018). The increase in $\mathrm{NO}_{3}{ }^{-}-\mathrm{N}$ and $\mathrm{NH}_{4}{ }^{+}-\mathrm{N}$

concentrations in soils after land-use change are evidently related to the increase in $\mathrm{N}$ input from fertilization (Asadiyan et al., 2013).

\subsection{Land-use conversion effects on different soil P forms}

bamboo plantations increased the resin- $\mathrm{P}_{\mathrm{i}}$ and $\mathrm{NaHCO}_{3}-\mathrm{P}_{\mathrm{i}}$ concentrations but decreased

the $\mathrm{NaHCO}_{3}-\mathrm{P}_{\mathrm{o}}$ concentration (Table 1). Similarly, Yang et al. (2010) found that

converting natural secondary forests to larch plantations increased the TP and iron-bound

$\mathrm{P}(\mathrm{Fe}-\mathrm{P})$ concentrations in soils but decreased the $\mathrm{MBP}$ and $\mathrm{NaHCO}_{3}-\mathrm{P}_{\mathrm{o}}$ concentrations.

The changes in soil $\mathrm{P}$ forms caused by land-use change have two possible 
reduced the organic $\mathrm{P}$ concentration in intensively managed rubber and oil palm plantations (Maranguit et al. 2017). In addition, Yang et al. (2012) showed that fertilization caused a significant increase in the inorganic $\mathrm{P}$ concentration and a significant decrease in the organic $\mathrm{P}$ concentration in soils. Thus, the increase in the concentration of inorganic $\mathrm{P}$ fractions is at least partially related to the application of phosphate fertilizer in the Moso bamboo plantation. In addition, the intensive management measures, e.g. deep tillage and fertilization, applied in the Moso bamboo plantation may decrease the organic P concentration since they can promote the mineralization of P-containing organic matter (Yang et al., 2012; Obour et al., 2017).

\subsection{Land-use conversion effects on different soil K forms} understand the response of $\mathrm{K}$ nutrient status to land-use conversion (Wang et al., 2016; Islam et al., 2017). The available $\mathrm{K}$ concentration increased after the conversion of natural evergreen broadleaf forests to Phyllostachys praecox stands and in the conversion from virgin natural forests to alder and sequoia plantations (Zhang et al. 2013; Moghimian et al. 2017). Likewise, our results indicated that conversion from broadleaf forests to Moso bamboo plantations significantly increased the concentrations of total $\mathrm{K}$, available $\mathrm{K}$, slowly available K, and mineral K (Fig. 3).

The $\mathrm{KCl}$ fertilizer applied in the Moso bamboo plantation was the possible source of the increased $\mathrm{K}$ in soils. The fertilizer can quickly increase the available $\mathrm{K}$, and a part of 
the available $\mathrm{K}$ will be transformed to slowly available $\mathrm{K}$ and mineral $\mathrm{K}$ forms (Rupa et al., 2003; Islam et al., 2017).

\subsection{Land-use conversion effects on soil microbial biomass and enzyme activity}

The soil microbial biomass is a sensitive index of the soil nutrient pool, since soil nutrients provide the basis for the survival of soil microbes (Guo et al., 2016; Vitali et al., 2016). In agreement with Fang et al. (2017), who reported that converting natural oldgrowth broadleaf Korean pine mixed forest to a spruce plantation caused a reduction in the soil MBC concentration, we noticed that the soil MBC concentration was lower in the Moso bamboo plantation than in the broadleaf forest (Fig. 4). In line with our previous study where the MBN concentration decreased significantly 10 years after the conversion from shrub forests to Chinese chestnut plantations (Li et al., 2014), the land-use change in this study decreased the concentrations of MBN and MBP (Fig. 4). The decreased concentrations of $\mathrm{MBC}, \mathrm{MBN}$ and $\mathrm{MBP}$ in the bamboo plantation might have been partially due to the lower $\mathrm{pH}$, which is known to inhibit microbial growth (Luo et al., 2013; Guo et al., 2016; Moghimian et al., 2017). Another possible explanation is the markedly decreased SOC concentration, which might have had a negative impact on the growth of soil microorganisms (Vitali et al., 2016; Moghimian et al., 2017).

The soil enzyme activity is one of the most sensitive indicators of soil nutrient status and fertility, and it is greatly affected by land-use conversion and alterations in management practices (Moghimian et al., 2017). Converting tropical forests to rubber 
plantations decreased the activity of acid phosphatase, catalase activity decreased after the conversion from a broadleaf forest to a Michelia macclurei Dandy plantation, and acid phosphatase activity decreased after converting a broadleaf forest to a Pinus massoniana Lamb plantation (Yang et al. 2012; Wang et al. 2013). In this study, the activities of protease, urease, acid phosphatase and catalase, involved in $\mathrm{N}$ and $\mathrm{P}$ cycling, were significantly lower in soils after the land-use change of broadleaf forests to bamboo plantations (Fig. 5). Low soil $\mathrm{pH}$ is likely to have a negative effect on the activity of some soil enzymes (Wallenius et al., 2011; Zhang et al., 2015b), which may partially explain the lower activities in bamboo plantation. Also, the lower activities might have resulted from lower microbial biomass. Since soil enzymes originate mainly from soil microorganisms, changes in microbial growth, activity and function resulting from land-use change could affect enzyme activities (Yang et al., 2012; Kader et al., 2017). Zhang et al. (2015b) found a significant relationship between the decrease in acid phosphatase activity and the application of calcium superphosphate fertilizer. Furthermore, urease activity decreased significantly with an increase in nitrogen fertilizer application (Shen et al. 2010). Thus, fertilization in the bamboo plantation might have decreased the soil enzyme activity. Soil enzyme activity is closely associated with the level of soil nutrients (Chen et al., 2003; Islam et al., 2011; Zhang et al., 2015b). Xing et al. (2010) reported that the decomposition of soil organic $\mathrm{N}$ into $\mathrm{NH}_{4}{ }^{+}-\mathrm{N}$ could be enhanced by increased activities of urease and protease in the subtropics of China. Chen (2003) found that soil acid phosphatase activity in a subtropical fir (Cunninghamia lanceolata) plantation in China was closely related with most of the inorganic $\mathrm{P}$ fractions except Ca-P. In this study, we 
502 found that acid phosphatase activity correlated positively with $\mathrm{MBP}$ and $\mathrm{NaHCO}_{3}-\mathrm{P}_{\mathrm{o}}(\mathrm{Fig}$.

503 6), and urease and protease activities correlated positively with the concentrations of MBN and WSON (Fig. 7). Therefore, the effects of land-use conversion on the soil enzyme activities may be attributed to its effect on the soil nutrient pools.

\section{Conclusions}

Converting natural evergreen broadleaf forests to intensively managed Moso bamboo

plantation significantly decreased the soil $\mathrm{pH}$ and the concentration and stock of SOC, but

significantly increased the concentrations and stocks of TN, TP and TK. Further, this land-

use conversion increased the concentrations of $\mathrm{NH}_{4}{ }^{+}-\mathrm{N}, \mathrm{NO}_{3}{ }^{-}-\mathrm{N}$, resin- $\mathrm{P}_{\mathrm{i}}, \mathrm{NaHCO}_{3}-\mathrm{P}_{\mathrm{i}}$,

$\mathrm{NaOH}-\mathrm{P}_{\mathrm{i}}, \mathrm{HCl}-\mathrm{P}_{\mathrm{i}}$, residual-P, available $\mathrm{K}$, slowly available $\mathrm{K}$ and mineral $\mathrm{K}$ but

significantly decreased the concentrations of WSON, $\mathrm{NaHCO}_{3}-\mathrm{P}_{\mathrm{o}}$, and $\mathrm{NaOH}-\mathrm{P}_{\mathrm{o}}$, as well

as the soil microbial biomass and enzyme activity. These results clearly demonstrate that

the aforementioned land-use conversion had positive effects on the soil inorganic $\mathrm{N}, \mathrm{P}$ and

K pools, while the effects on the soil organic N, P and K pools were negative. Therefore, to manage the Moso bamboo plantations sustainably, it is advisable to increase the organic nutrient pools by applying organic fertilizers and re-establishing understory vegetation. As the duration under intensive management will markedly affect the soil nutrient status, both the short- and long-term effects of intensive management on soil N, P and K forms and enzyme activity need to be explored in further studies. 


\section{Acknowledgements}

This research was financially supported by the National Natural Science Foundation of China (No. 31470626) and the Natural Science Foundation for Distinguished Young Scholars of Zhejiang Province (No. LR18C160001).

\section{References}

Asadiyan, M., Hojjati, S.M., Pourmajidian, M.R., Fallah, A., 2013. Impact of land-use management on nitrogen transformation in a mountain forest ecosystem in the north of Iran. J. Forestry Res. 24, 115-119.

Bhattacharyya, P., Chakrabarti, K., Chakraborty, A., 2005. Microbial biomass and enzyme activities in submerged rice soil amended with municipal solid waste compost and decomposed cow manure. Chemosphere 60, 310-318.

Brookes, P.C., Powlson, D.S., Jenkinson, D.S., 1982. Measurement of microbial biomass phosphorus in soil. Soil Biol. Biochem. 14, 319-329.

Burton, J., Chen, C.R., Xu, Z.H., Ghadiri, H., 2007. Gross nitrogen transformations in adjacent native and plantation forests of subtropical Australia. Soil Biol. Biochem. 39, 426-433.

Burton, J., Chen, C.R., Xu, Z.H., Ghadiri, H., 2010. Soil microbial biomass, activity and community composition in adjacent native and plantation forests of subtropical Australia. J. Soil. Sediment. 10, 1267-1277. 
Chang, E.H., Chung, R.S., Tsai, Y.H., 2007. Effect of different application rates of organic fertilizer on soil enzyme activity and microbial population. J. Soil Sci. Plant Nut. 53, 132-140.

Chavarría, D.N., Verdenelli, R.A., Serri, D.L., Restovich, S.B., Andriulo, A.E., Meriles, J.M., Vargas-Gil, S., 2016. Effect of cover crops on microbial community structure and related enzyme activities and macronutrient availability. Eur. J. Soil Biol. 76, 7482.

Chen, C.R., Xu, Z.H., 2008. Analysis and behavior of soluble organic nitrogen in forest soils. J. Soil. Sediment. 8, 363-378.

Chen, H., 2003. Phosphatase activity and P fractions in soils of an 18-year-old Chinese fir (Cunninghamia lanceolata) plantation. Forest Ecol. Manag. 178, 301-310.

Chen, L.C., Wang, H., Yu, X., Zhang, W.D., Lü, X.T., Wang, S.L., 2017. Recovery time of soil carbon pools of conversional Chinese fir plantations from broadleaved forests in subtropical regions, china. Sci. Total Environ. 587, 296-304.

Dangal, S.P., Das, A.K., Paudel, S.K., 2017. Effectiveness of management interventions on forest carbon stock in planted forests in Nepal. J. Environ. Manage. 196, 511-517.

Darunsontaya, T., Suddhiprakarn, A., Kheoruenromne, I., Prakongkep, N., Gilkes, R. J., 2012. The forms and availability to plants of soil potassium as related to mineralogy for upland Oxisols and Ultisols from Thailand. Geoderma 170, 11-24.

Dawoe, E.K., Quashie-Sam, J.S., Oppong, S.K., 2014. Effect of land-use conversion from forest to cocoa agroforest on soil characteristics and quality of a Ferric Lixisol in lowland humid Ghana. Agroforestry Syst. 88, 87-99. 
Don, A., Schumacher, J., Freibauer, A., 2011. Impact of tropical land-use change on soil organic carbon stocks-a meta-analysis. Global Change Biol. 17, 1658-1670.

Eriksson, A.K., Gustafsson, J.P., Hesterberg, D., 2015. Phosphorus speciation of clay fractions from long-term fertility experiments in Sweden. Geoderma 241, 68-74.

Fang, X., Zhang, J., Meng, M.J., Guo, X.P., Wu, Y.W., Liu, X., Zhao, K.L., Ding, L.Z., Shao, Y.F., Fu, W.J., 2017. Forest-type shift and subsequent intensive management affected soil organic carbon and microbial community in southeastern China. Eur. J. Forest Res. 136, 689-697.

Fukuzawa, K., Shibata, H., Takagi, K., Nomura, M., Kurima, N., Fukazawa, T., Satoh, F., Sasa, K., 2006. Effects of clear-cutting on nitrogen leaching and fine root dynamics in a cool-temperate forested watershed in northern Japan. Forest Ecol. Manag. 225, 257-261.

Ge, T.D., Wei, X,M., Bahar, R.S., Zhu, Z.K., Hu, Y.J., Kuzyakov, Y., Jones, D.L., Jinshui Wu, J.S., 2017. Stability and dynamics of enzyme activity patterns in the rice rhizosphere: Effects of plant growth and temperature. Soil Biol. Biochem. 113: 108115.

Gee, G.W., Bauder, J.W., 1986. Particle-size analysis. In: Klute, A., (ed) Methods of soil analysis. Part 1, vol 9, 2nd edn, Agron Monogr. Soil Sci Soc Am J, Madison, pp 383412.

Guan, F.Y., Tang, X.L., Fan, S.H., Zhao, J.C., Peng, C., 2015. Changes in soil carbon and nitrogen stocks followed the conversion from secondary forest to Chinese fir and Moso bamboo plantations. Catena 133, 455-460. 
Guillaume, T., Damris, M., Kuzyakov, Y., 2015. Losses of soil carbon by converting tropical forest to plantations: erosion and decomposition estimated by $\delta^{13} \mathrm{C}$. Global Change Biol. 21, 3548-3560.

Guo, X., Chen, H.Y.H., Meng, M., Biswas, S.R., Ye, L. Zhang, J., 2016. Effects of land use change on the composition of soil microbial communities in a managed subtropical forest. Forest Ecol. Manag. 373, 93-99.

Hanway, J.J., Heidel, H., 1952. Soil analysis methods as used in Iowa State College Soil Testing Laboratory. Iowa Agric 57, 1-31

Hedley, M.J., Stewart, J.W.B., Chauhan, B.S., 1982. Changes in inorganic and organic soil phosphorus fractions induced by cultivation practices and by laboratory incubations. Soil Sci. Soc. Am. J. 46, 970-976.

Hu, S.D., Li, Y.F., Chang, S.X., Li, Y.C., Yang, W.J., Fu, W.J., Liu, J., Jiang, P.K., Lin, Z.W. 2018. Soil autotrophic and heterotrophic respiration respond differently to land-use change and variations in environmental factors. Agr. Forest Meteorol. 250, 290-298.

Islam, A., Karim, A.J.M.S., Solaiman, A.R.M., Saleque, M.A., Islam, M.S., 2017. Eightyear long potassium fertilization effects on quantity/intensity relationship of soil potassium under double rice cropping. Soil Till. Res. 169, 99-117.

Islam, M.R., Chauhan, P.S., Kim, Y., Kim, M., Sa, T., 2011. Community level functional diversity and enzyme activities in paddy soils under different long-term fertilizer management practices. Biol. Fert. Soils 47, 599-604.

Johnson, J.L., Temple, K.L., 1964. Some variables affecting the measurement of "Catalase 
Activity" in soill. Soil Sci. Soc. Am. J. 28, 207-209.

Jones, D.L., Willett, V.B., 2006. Experimental evaluation of methods to quantify dissolved organic nitrogen (DON) and dissolved organic carbon (DOC) in soil. Soil Biol. Biochem. 38, 991-999.

Kader, M.A., Yeasmin, S., Akter, M., Sleutel, S., 2017. Response of hydrolytic enzyme activities and nitrogen mineralization to fertilizer and organic matter application in subtropical paddy soils. Eur. J. Soil Biol. 80, 27-34.

Kandeler, E., Gerber, H., 1988. Short-term assay of soil urease activity using colorimetric determination of ammonium. Biol. Fert. Soils 6, 68-72.

Ladd, J.N., Butler, J.H.A., 1972. Short-term assays of soil proteolytic enzyme activities using proteins and dipeptide derivatives as substrates. Soil Biol. Biochem. 4, 19-30.

Li, R., Tao, R., Ling, N., Chu, G.X., 2017a. Chemical, organic and bio-fertilizer management practices effect on soil physicochemical property and antagonistic bacteria abundance of a cotton field: implications for soil biological quality. Soil Till. Res. 167, 30-38.

Li, Y., Lee, C.G., Watanabe, T., Murase, J., Asakawa, S., Kimura, M., 2011. Identification of microbial communities that assimilate substrate from root cap cells in an aerobic soil using a DNA-SIP approach. Soil Biol. Biochem. 43, 1928-1935.

Li, Y.C., Li, Y.F., Chang, S.X., Liang, X., Qin, H., Chen, J.H., Xu, Q.F., 2017b. Linking soil fungal community structure and function to soil organic carbon chemical composition in intensively managed subtropical bamboo forests. Soil Biol. Biochem. 107, 19-31. 
Li, Y.F., Hu, S.D., Chen, J.H., Müller, K., Li, Y.C., Fu, W.J., Lin, Z.W., Wang, H.L., 2018. Effects of biochar application in forest ecosystems on soil properties and greenhouse gas emissions: a review. J. Soil. Sediment. 18, 546-563.

Li, Y.F., Zhang, J.J., Chang, S.X., Jiang, P.K., Zhou, G.M., Fu, S.L., Yan, E.R., Wu, J.S., Lin, L., 2013. Long-term intensive management effects on soil organic carbon pools and chemical composition in Moso bamboo (phyllostachys pubescens) forests in subtropical China. Forest Ecol. Manag. 303, 121-130.

Li, Y.F., Zhang, J.J., Chang, S.X., Jiang, P.K., Zhou, G.M., Shen, Z.M., Wu, J.S., Lin, L., Wang, Z.S., Shen, M.C., 2014. Converting native shrub forests to Chinese chestnut plantations and subsequent intensive management affected soil $\mathrm{C}$ and $\mathrm{N}$ pools. Forest Ecol. Manag. 312, 161-169.

Liu, D., Li, S., Islam, E., Chen, J.Z., Wu, J.C., Ye, Z.Q., Peng, D.L., Yan, W.B., Lu, K.P., 2015. Lead accumulation and tolerance of Moso bamboo (Phyllostachys pubescens) seedlings: applications of phytoremediation. J. Zhejiang Univ.-Sci. B. 16, 123-130.

Liu, H., Li, J., Zhao, Y., Xie, K., Tang, X., Wang, S., Li, Z., Liao, Y., Xu, J., Di, H., Li, Y., 2018. Ammonia oxidizers and nitrite-oxidizing bacteria respond differently to long-term manure application in four paddy soils of south of China. Sci. Total Environ. 633, 641-648.

Luo, Y., Durenkamp, M., De Nobili, M., Lin, Q., Devonshire, B.J., Brookes, P.C., 2013. Microbial biomass growth, following incorporation of biochars produced at $350{ }^{\circ} \mathrm{C}$ or $700{ }^{\circ} \mathrm{C}$, in a silty-clay loam soil of high and low pH. Soil Biol. Biochem. 57, 513-523. 
656

657

658

659

660

661

662

663

664

665

666

667

668

669

670

671

672

673

674

675

676

677

Luo, Y., Zang, H., Yu, Z., Chen, Z., Gunina, A., Kuzyakov, Y., Xu, J., Zhang, K., Brookes, P.C., 2017. Priming effects in biochar enriched soils using a three-sourcepartitioning approach: ${ }^{14} \mathrm{C}$ labelling and ${ }^{13} \mathrm{C}$ natural abundance. Soil Biol. Biochem. 106, 28-35.

Ma, B., Wang, H.Z., Dsouza, M., Lou, J., He, Y., Dai, Z.M., Brookes, P.C., Xu, J.M., Gilbert, J.A., 2016. Geographic patterns of co-occurrence network topological features for soil microbiota at continental scale in eastern China. The ISME Journal 10, 1891-1901.

Malchair, S., Carnol, M., 2009. Microbial biomass and C and N transformations in forest floors under European beech, sessile oak, Norway spruce and Douglas-fir at four temperate forest sites. Soil Biol. Biochem. 41, 831-839.

Mancinelli, R., Campiglia, E., Tizio, A.D., Marinari, S., 2010. Soil carbon dioxide emission and carbon content as affected by conventional and organic cropping systems in Mediterranean environment. Appl. Soil Ecol. 46, 64-72.

Maranguit, D., Guillaume, T., Kuzyakov, Y., 2017. Land-use change affects phosphorus fractions in highly weathered tropical soils. Catena 149, 385-393.

Marschner, P., Kandeler, E., Marschner, B., 2003. Structure and function of the soil microbial community in a long-term fertilizer experiment. Soil Biol. Biochem. 35, 453-461.

Moghimian, N., Hosseini, S.M., Kooch, Y., Darki, B.Z., 2017. Impacts of changes in land use/cover on soil microbial and enzyme activities. Catena, 157, 407-414.

Murphy, J., Riley, J.P., 1962. A modified single solution method for the determination of 
Obour, A.K., Mikha, M.M., Holman, J.D., Stahlman, P.W., 2017. Changes in soil surface chemistry after fifty years of tillage and nitrogen fertilization. Geoderma 308, 46-53. long-term agricultural cultivation and land use conversion on soil nutrient contents in the Sanjiang Plain. Catena 104, 243-250.

Pransiska, Y., Triadiati, T., Tjitrosoedirjo, S., Hertel, D., Kotowska, M.M., 2016. Forest conversion impacts on the fine and coarse root system, and soil organic matter in tropical lowlands of Sumatera (Indonesia). Forest Ecol. Manag. 379, 288-298.

Ross, D.J., Tate, K.R., Scott, N.A., Feltham, C.W., 1999. Land-use change: effects on soil carbon, nitrogen and phosphorus pools and fluxes in three adjacent ecosystems. Soil Biol. Biochem. 31, 803-813.

Rupa, T.R., Srivastava, S., Swarup, A., Sahoo, D., Tembhare, B.R., 2003. The availability of potassium in Aeric Haplaquept and Typic Haplustert as affected by long-term cropping, fertilization and manuring. Nutr. Cycl. Agroecosys. 65, 1-11.

Sainju, U.M., Lenssen, A.W., Caesar-TonThat, T., Jabro, J.D., Lartey, R.T., Evans, R.G., Allen, B.L., 2012. Dryland soil nitrogen cycling influenced by tillage, crop rotation, and cultural practice. Nutr. Cycl. Agroecosys. 93, 309-322.

Schimel, J.P., Bennett, J., 2004. Nitrogen mineralization: challenges of a changing paradigm. Ecology 85, 591-602.

Schoenau, J.J., Huang, W.Z., 1991. Anionâ-exchange membrane, water, and sodium bicarbonate extractions as soil tests for phosphorus. Commun. Soil Sci. Plan. 22, 465- 
Scott, E.E., Rothstein, D.E., 2011. Amino acid uptake by temperate tree species characteristic of low- and high-fertility habitats. Oecologia 167, 547-557.

Shen, W.S., Lin, X.G., Shi, W.M., Ju, M., Nan, G., Zhang, H.Y., Yin, R., He, X.H., 2010. Higher rates of nitrogen fertilization decrease soil enzyme activities, microbial functional diversity and nitrification capacity in a Chinese polytunnel greenhouse vegetable land. Plant Soil 337, 137-150.

Sheng, Z., Zhou, P., Zhang, Y., Kuzyakov, Y., Zhou, Q., Ge, T., Wang, C., 2015. Loss of labile organic carbon from subsoil due to land-use changes in subtropical china. Soil Biol. Biochem. 88, 148-157.

Tabatabai, M.A., Bremner, J.M., 1969. Use of $p$-nitrophenyl phosphate for assay of soil phosphatase activity. Soil Biol. Biochem. 1, 301-307.

Tao, R., Wakelin, S.A., Liang, Y., Hu, B., Chu, G., 2018. Nitrous oxide emission and denitrifier communities in drip-irrigated calcareous soil as affected by chemical and organic fertilizers. Sci. Total Environ. 612, 739-749.

Tiecher, T., Calegari, A., Caner, L., Rheinheimer, D.D.S., 2017. Soil fertility and nutrient budget after 23-years of different soil tillage systems and winter cover crops in a subtropical Oxisol. Geoderma 308, 78-85.

Vance, E.D., Brookes, P.C., Jenkinson, D.S., 1987. An extraction method for measuring soil microbial biomass C. Soil Biol. Biochem. 19, 703-707.

Vitali, F., Mastromei, G., Senatore, G., Caroppo, C., Casalone, E., 2016. Long lasting effects of the conversion from natural forest to poplar plantation on soil microbial 
communities. Microbiol. Res. 182, 89-98.

Wallenius, K., Rita, H., Mikkonen, A., Lappi, K., Lindström, K., Hartikainen, H., Raateland, A., Niemi, R.M., 2011. Effects of land use on the level, variation and spatial structure of soil enzyme activities and bacterial communities. Soil Biol. Biochem. 43, 1464-1473.

Wang, H.Y., Cheng, W., Li, T., Zhou, J.M., Chen, X.Q., 2016. Can nonexchangeable potassium be differentiated from structural potassium in soils? Pedosphere 26, 206215.

Wang, Q., Wang, S., Yu, X., 2011. Decline of soil fertility during forest conversion of secondary forest to Chinese fir plantations in subtropical china. Land Degrad. Dev. $22,444-452$.

Wang, Q., Xiao, F., He, T., Wang, S., 2013. Responses of labile soil organic carbon and enzyme activity in mineral soils to forest conversion in the subtropics. Ann. Forest Sci. 70, 579-587.

Wang, X.H., Kent, M., Fang, X.F., 2007. Evergreen broad-leaved forest in Eastern China: Its ecology and conservation and the importance of resprouting in forest restoration. Forest Ecol. Manag. 245, 76-87.

Wei, X.M., Hu, Y.J., Peng, P.Q., Zhu, Z.K, Atere, C.T., G O’Donnell, A., Wu, J.S., Ge, T.D., 2017. Effect of P stoichiometry on the abundance of nitrogen-cycle genes in phosphorus-limited paddy soil. Biol. Fert. Soils 53: 767-776.

World Reference Base for Soil Resources (WRB), 2006. A Framework for International Classification, Correlation and Communication. Food and Agriculture Organization 
of the United Nations, Rome.

Wu, J., Joergensen, R.G., Pommerening, B., Chaussod, R., Brookes, P.C., 1990. Measurement of soil microbial biomass $\mathrm{C}$ by fumigation-extraction-an automated procedure. Soil Biol. Biochem. 22, 1167-1169.

Wu, J.S., Jiang, P.K., Chang, S.X., Xu, Q.F., Yang, L., 2010. Dissolved soil organic carbon and nitrogen were affected by conversion of native forests to plantations in subtropical china. Can. J. Soil Sci. 90, 27-36.

Xie, X.F., Pu, L.J., Wang, Q.Q., Zhu, M., Xu, Y., Zhang, M., 2017. Response of soil physicochemical properties and enzyme activities to long-term reclamation of coastal saline soil, Eastern China. Sci. Total Environ. 607, 1419-1427.

Xing, S.H., Chen, C.R., Zhou, B.Q., Zhang, H., Nang, Z.M., Xu, Z.H., 2010. Soil soluble organic nitrogen and active microbial characteristics under adjacent coniferous and broadleaf plantation forests. J. soil. Sediment. 10, 748-757.

Xu, Z.F., Hu, R., Xiong, P., Wan, C., Cao, G., Liu, Q., 2010. Initial soil responses to experimental warming in two contrasting forest ecosystems, Eastern Tibetan Plateau, China: Nutrient availabilities, microbial properties and enzyme activities. Appl. Soil Ecol. 46, 291-299.

Yan, E.R., Wang, X.H., Huang, J.J., Li, G.Y., Zhou, W., 2008. Decline of soil nitrogen mineralization and nitrification during forest conversion of evergreen broad-leaved forest to plantations in the subtropical area of Eastern China. Biogeochemistry 89, 239-251.

Yan, W.B., Mahmood, Q., Peng, D.L., Fu W.J., Chen, T., Wang, Y., Li, S., Chen, JR., Liu, 
D., 2015. The spatial distribution pattern of heavy metals and risk assessment of moso bamboo forest soil around lead-zinc mine in Southeastern China. Soil Till. Res. $153,120-130$.

Yang, J.C., Huang, J.H., Pan, Q.M., Tang, J.W., Han, X.G., 2004. Long-term impacts of land-use change on dynamics of tropical soil carbon and nitrogen pools, J. Environ. Sci-China. 16, 256-261.

Yang, K., Zhu, J.J., Yan, Q.L., Sun, J.X.O.S., 2010. Changes in soil P chemistry as affected by conversion of natural secondary forests to larch plantations. Forest Ecol. Manag. 260, 422-428.

Yang, M., Li, Y.F, Li, Y.C., Chang, S.X., Yue, T., Fu, W.J., Jiang, P.K. Zhou, G.M., 2017. Effects of inorganic and organic fertilizers on soil $\mathrm{CO}_{2}$ efflux and labile organic carbon pools in an intensively managed Moso bamboo (Phyllostachys pubescens) plantation in subtropical China. Commun. Soil Sci. Plan. 48, 332-344.

Yang, W., Cheng, H., Hao, F., Ouyang, W., Liu, S., Lin, C., 2012. The influence of landuse change on the forms of phosphorus in soil profiles from the Sanjiang Plain of China. Geoderma 189, 207-214.

Yuan, H.Z., Ge, T.D., Chen, X.B., Liu, S.L., Zhu, Z.K, Wu, X.H., Wei, W.X., Whiteley, A.S., Wu, J.S., 2015. Abundance and diversity of $\mathrm{CO}_{2}$-assimilating bacteria and algae within red agricultural soils are modulated by changing management practice. Microl. Ecol. 70, 971-980.

Yuen, J.Q., Fung, T., Ziegler, A.D., 2017. Carbon stocks in bamboo ecosystems worldwide: Estimates and uncertainties. Forest Ecol. Manag. 393, 113-138. 
Yüksek, T., Göl, C., Yüksek, F., Yüksel, E.E., 2009. The effects of land-use changes on soil properties: the conversion of alder coppice to tea plantations in the Humid Northern Blacksea Region. Afr. J. Agr. Res. 4, 665-674.

Zhang, C.S., Xie, G.D., Fan, S.H., Zhen, L., 2010. Variation in vegetation structure and soil properties, and the relation between understory plants and environmental variables under different phyllostachys pubescens forests in southeastern China. Environ. Manage. 45, 779-792.

Zhang, J.J., Li, Y.F., Chang, S.X., Qin, H., Fu, S.L., Jiang, P.K., 2015a. Understory management and fertilization affected soil greenhouse gas emissions and labile organic carbon pools in a Chinese chestnut plantation. Forest Ecol. Manag. 337, 126134.

Zhang, J.J., Li, Y.F., Chang, S.X., Jiang, P.K., Zhou, G.M., Liu, J., Wu, J.S., Shen, Z.M., 2014. Understory vegetation management affected greenhouse gas emissions and labile organic carbon pools in an intensively managed Chinese chestnut plantation. Plant Soil 376, 363-375.

Zhang, R., Zhang, Y.L., Song, L.L., Song, X.Z., Hänninen, H., Wu, J.S. 2017a. Biochar enhances nut quality of torreya grandis, and soil fertility under simulated nitrogen deposition. Forest Ecol. Manag. 391, 321-329.

Zhang, T., Li, Y.F., Chang, S.X., Jiang, P.K., Zhou, G.M., Liu, J., Lin, L., 2013. Converting paddy fields to Lei bamboo (Phyllostachys praecox) stands affected soil nutrient concentrations, labile organic carbon pools, and organic carbon chemical compositions. Plant Soil 367, 249-261. 

Liu, X.Y., Sun, X.M., 2015b. Responses of absolute and specific soil enzyme activities to long term additions of organic and mineral fertilizer. Sci. Total Environ. $536,59-67$.

Zhang, Z.L., Yuan, Y.S., Zhao, W.Q., He, H.L., Li, D.D., He, W., Liu, Q., Yin, H.J., 2017b. Seasonal variations in the soil amino acid pool and flux following the conversion of a natural forest to a pine plantation on the eastern Tibetan plateau, China. Soil Biol. Biochem. 105, 1-11. 
Fig. 1 Effects of conversion from evergreen broadleaf forests to Moso bamboo plantations on the total stocks ( $\mathrm{a}, \mathrm{c}$, e and $\mathrm{g}$ ) and concentrations (b, d, f and $\mathrm{h}$ ) of $\mathrm{C}, \mathrm{N}, \mathrm{P}$ and $\mathrm{K}$ in soils. Error bars are the standard deviations of the mean $(n=4)$; different lowercase letters within each panel indicate significant differences between different land-use types in each soil layer at $P=0.05$ level based on the least significant difference (LSD) test.

Fig. 2 Effects of conversion from evergreen broadleaf forests to Moso bamboo plantations on the (a) $\mathrm{NH}_{4}{ }^{+}-\mathrm{N}$ concentration, (b) $\mathrm{NO}_{3}{ }^{-}-\mathrm{N}$ concentration, and (c) water soluble organic $\mathrm{N}(\mathrm{WSON})$ concentration in soils. Error bars are standard deviations of the mean $(n=4)$; different lowercase letters within each panel indicate significant differences between difference (LSD) test. based on the least significant difference (LSD) test.

Fig. 4 Effects of conversion from evergreen broadleaf forests to Moso bamboo plantations 
on the (a) microbial biomass $\mathrm{C}$, (b) microbial biomass $\mathrm{N}$, and (c) microbial biomass $\mathrm{P}$.

Error bars are the standard deviations of the mean $(n=4)$; different lowercase letters within each panel indicate significant differences between different land-use types in each soil layer at $P=0.05$ level based on the least significant difference (LSD) test.

Fig. 5 Effects of conversion from evergreen broadleaf forests to Moso bamboo plantations on the soil (a) protease activity, (b) urease activity, (c) acid phosphatase activity, and (d) catalase activity. Error bars are the standard deviations of the mean $(n=4)$; different lowercase letters within each panel indicate significant differences between different landuse types in each soil layer at $P=0.05$ level based on the least significant difference (LSD) test.

Fig. 6 Relationship between acid phosphatase activity and (a) microbial biomass P, (b) $\mathrm{NaHCO}_{3}-\mathrm{P}_{\mathrm{O}}$, and (c) $\mathrm{NaHCO}_{3}-\mathrm{P}_{\mathrm{i}}$ in the evergreen broadleaf forest and Moso bamboo plantation.

Fig. 7 Relationships (a-d) between urease activity and the concentrations of $\mathrm{NH}_{4}{ }^{+}-\mathrm{N}$, $\mathrm{NO}_{3}{ }^{-}-\mathrm{N}, \mathrm{WSON}$ and $\mathrm{MBN}$, and (e-h) between protease activity and the concentrations of $\mathrm{NH}_{4}{ }^{+}-\mathrm{N}, \mathrm{NO}_{3}{ }^{-}-\mathrm{N}, \mathrm{WSON}$ and $\mathrm{MBN}$ in the evergreen broadleaf forest and Moso bamboo plantation. WSON: water soluble organic N; MBN: microbial biomass $\mathrm{N}$. 


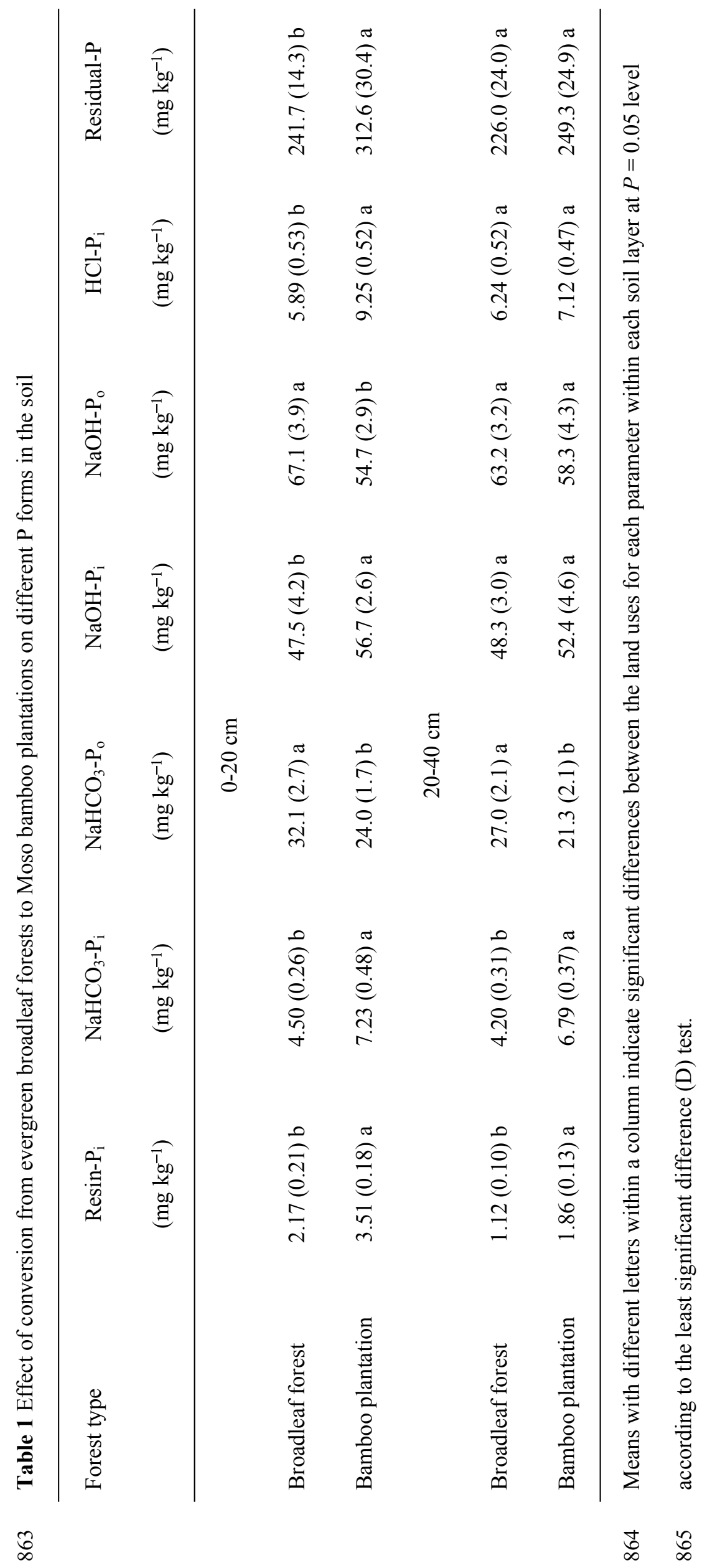



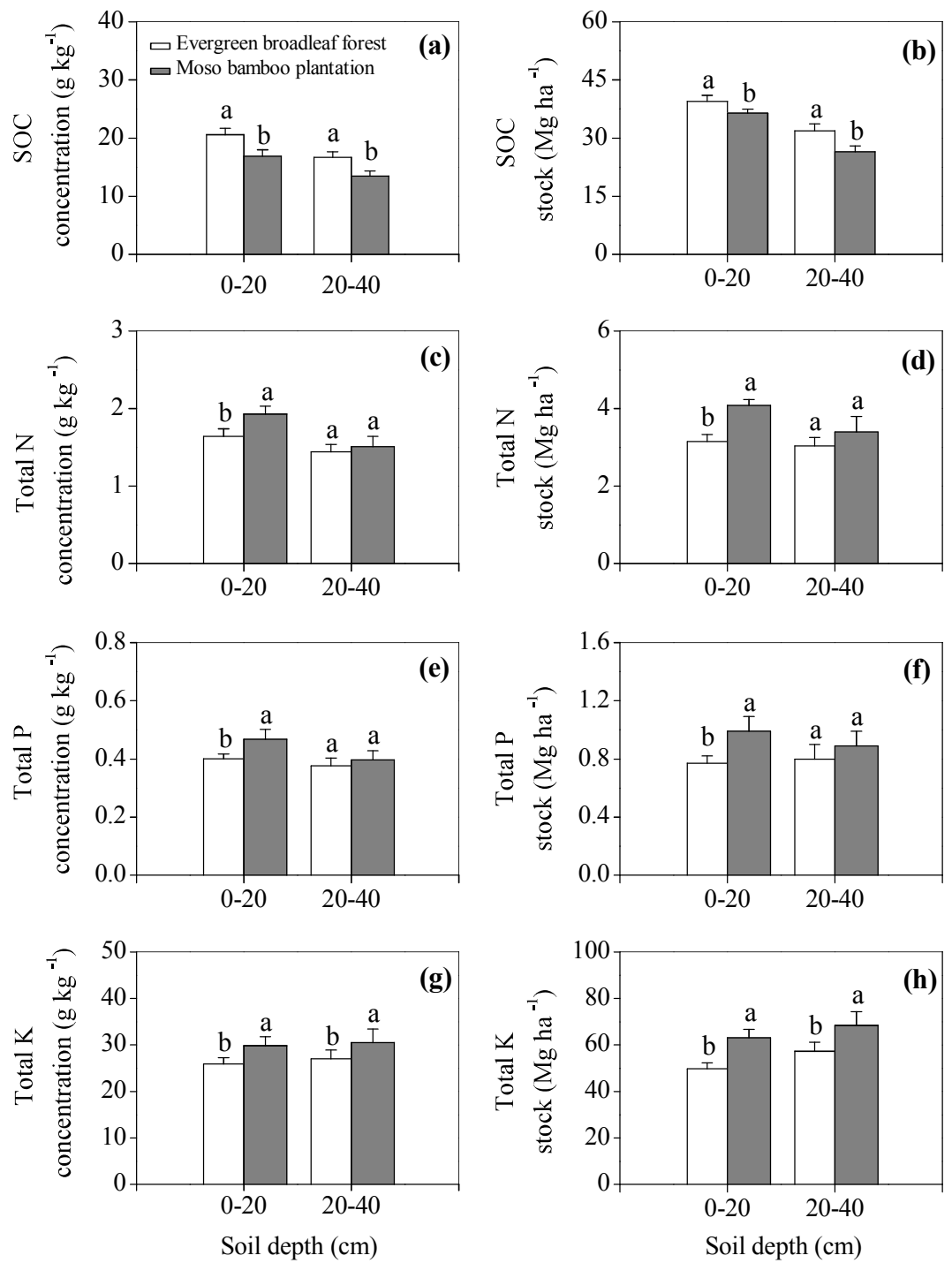

866

867

Fig. 1 

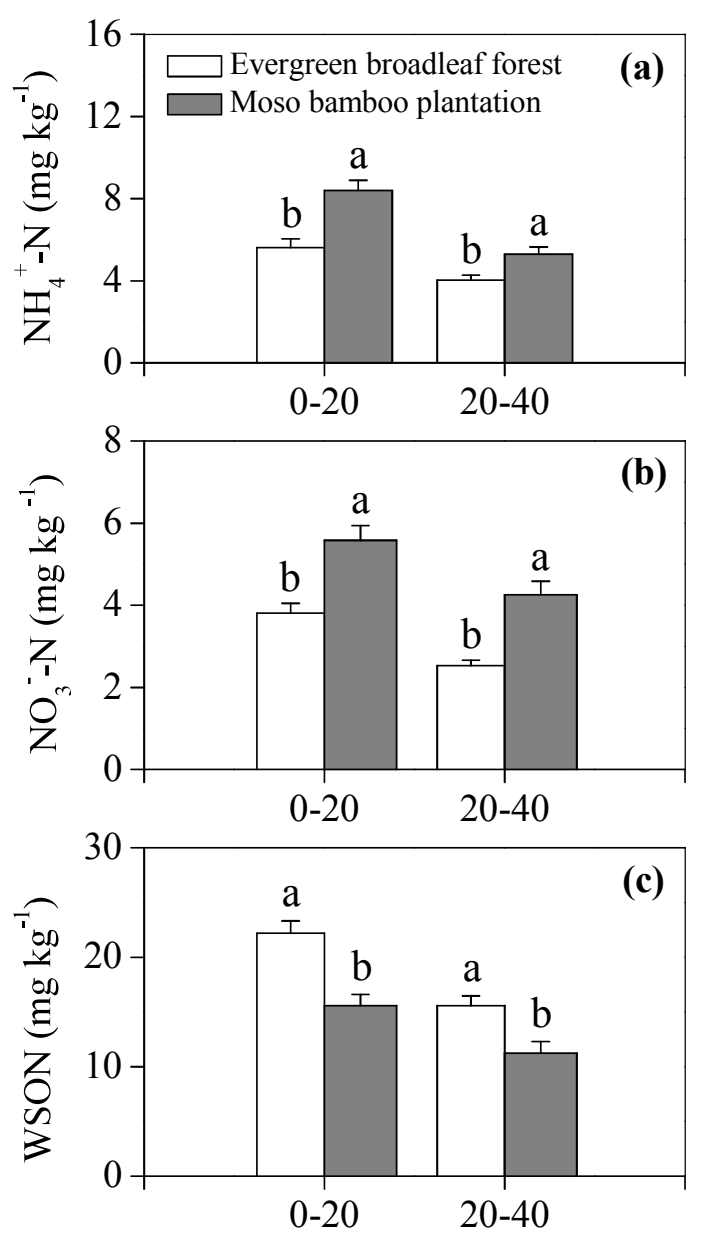

Soil depth (cm)

870

871

872

Fig. 2 

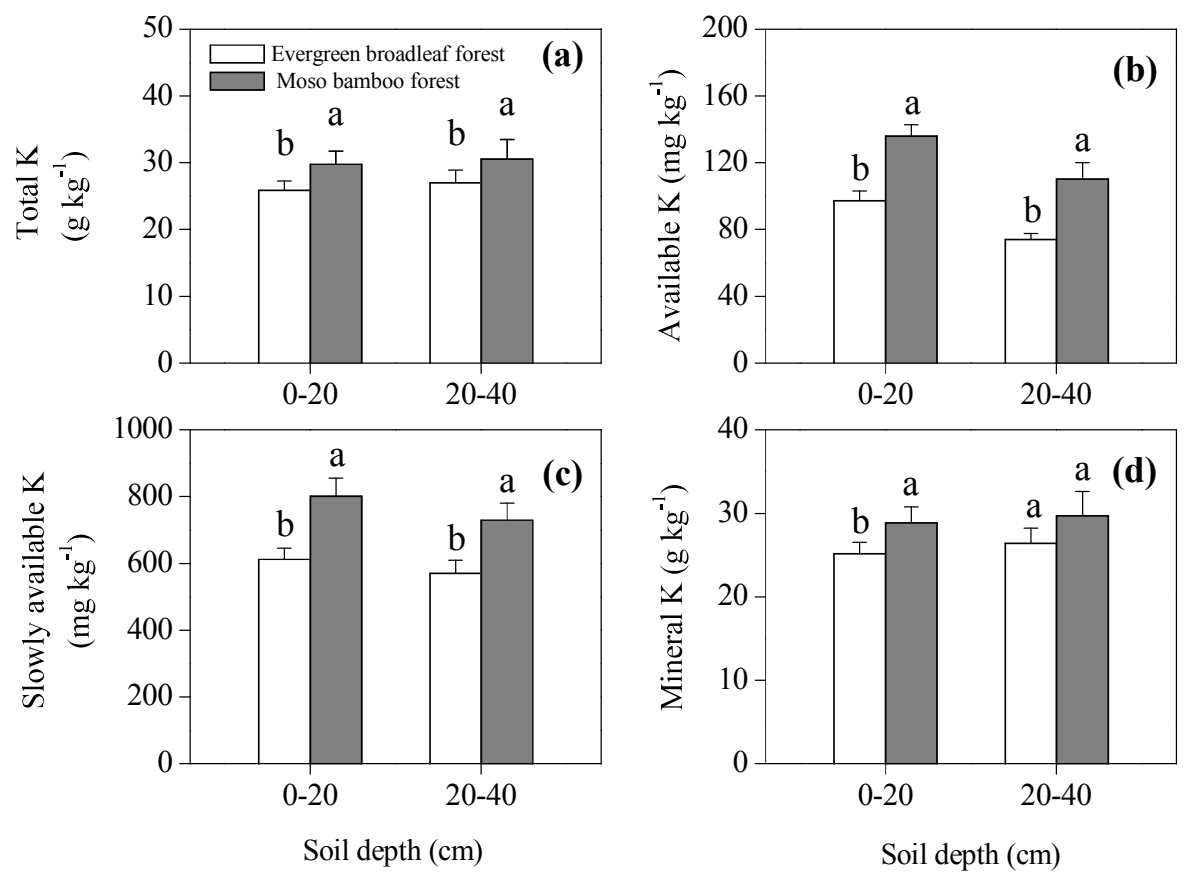

874

875

$876 \quad$ Fig. 3 

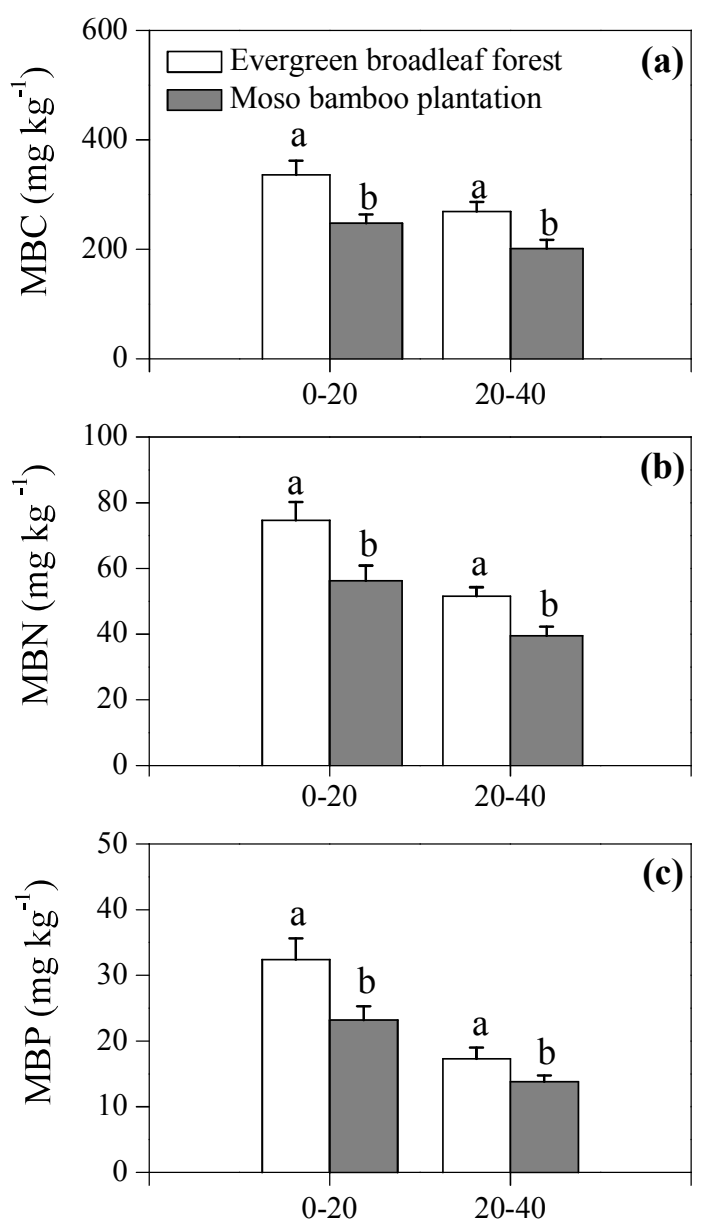

Soil depth (cm)

$880 \quad$ Fig. 4 

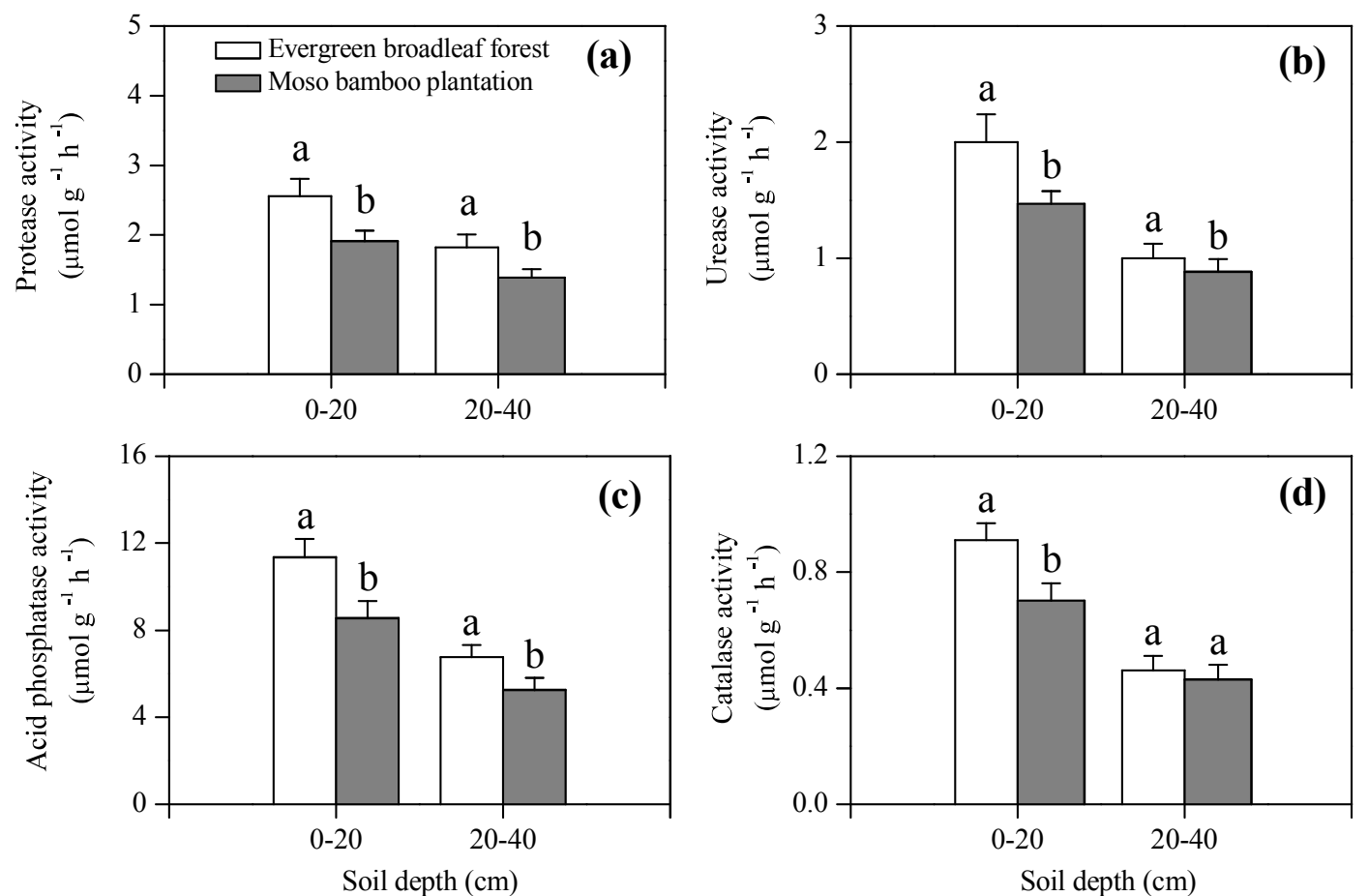

Fig. 5 

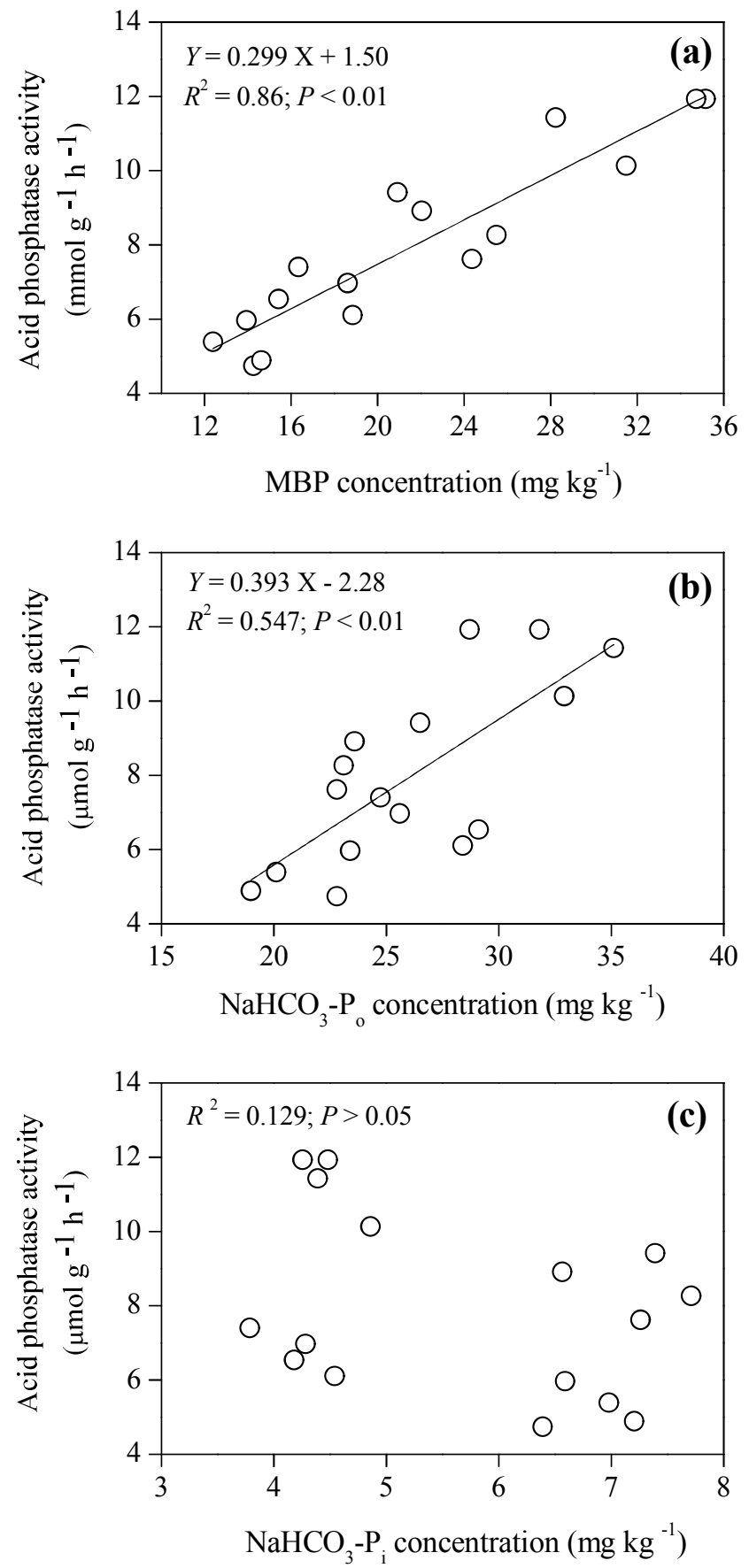

886

Fig. 6 

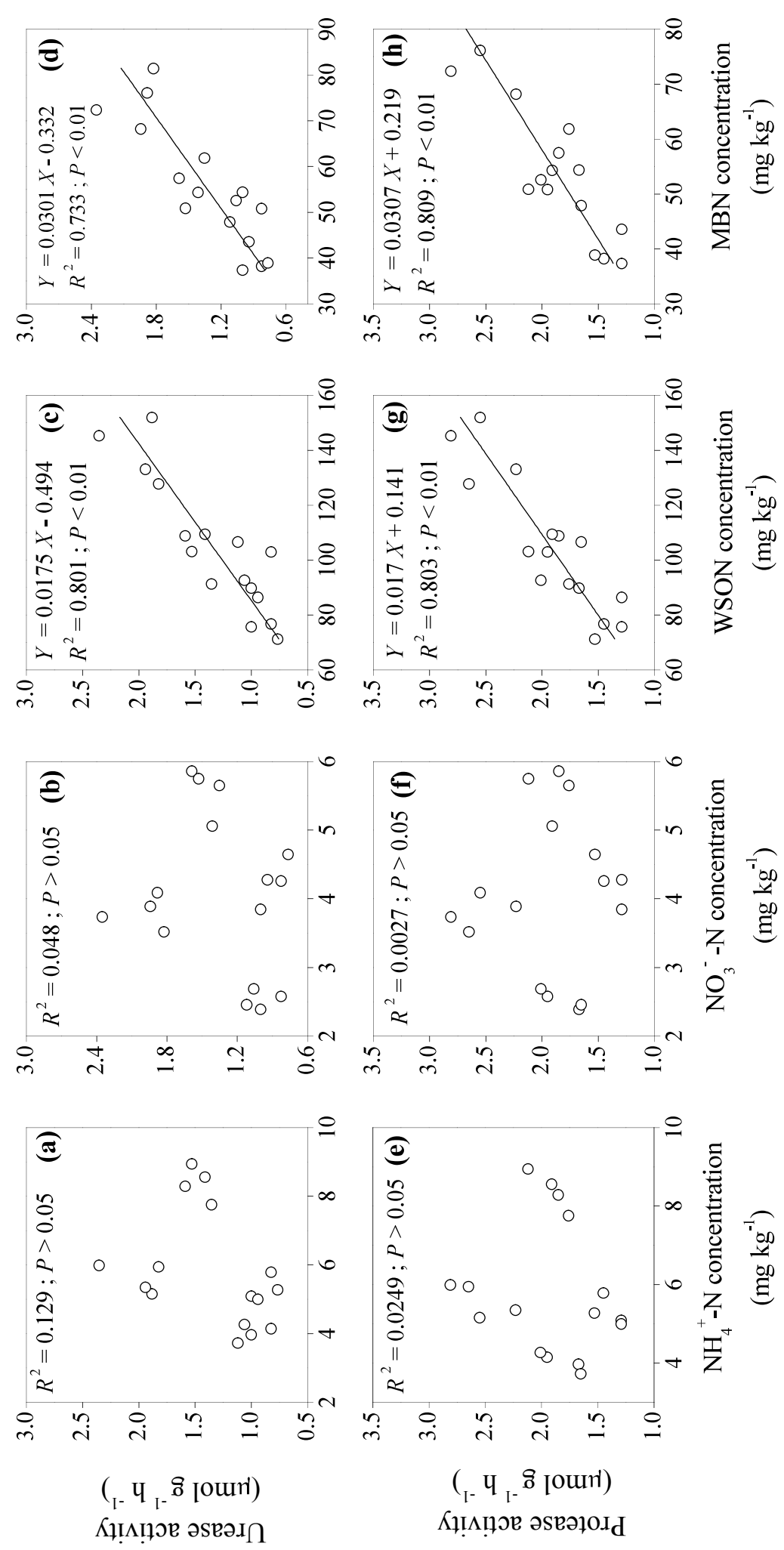

กำ 